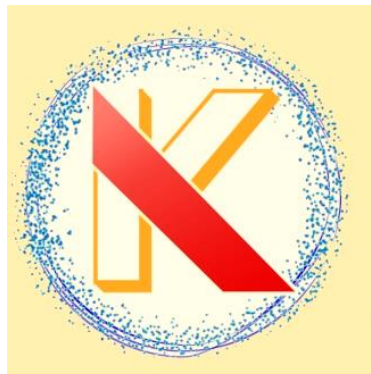

\title{
Analisis Formalin Secara Kualitatif pada Bakso dan Mie Basah di Kecamatan Sukarame, Wayhalim, dan Sukabumi
}

\section{[Qualitative Formaline Analysis on Meatball and Wet Noodle in Sukarame, Wayhalim, and Sukabumi]}

\author{
Riri Fauziyya* dan Anjar Hermadi Saputro \\ Program Studi Farmasi, Jurusan Sains, Institut Teknologi Sumatera, Lampung \\ ${ }^{*}$ Corresponding author : riri.fauziyya@fa.itera.ac.id (hp: +6288267061412)
}

\begin{abstract}
Meatballs and wet noodles are foods that are favored by the community. The high water content causes these two types of food to be vulnerable and easily damaged in storage. The addition of chemicals such as preservatives in the manufacture of food products is carried out by producers so that the products are more durable, economical, and produce maximum profit. One chemical that is often misused for food preservatives is formaldehyde. Formalin is a dangerous chemical that is carcinogenic, mutagenic, corrosive, and irritating. This study aims to determine whether there is formalin content in meatballs and wet noodles that are sold in the districts of Sukarame, Wayhalim, and Sukabumi. This research was conducted in a qualitative analysis using Schiff's reagent on 30 samples of meatballs and 30 samples of wet noodles which were sold in Sukarame, Wayhalim, and Sukabumi. The results showed that 10 samples of meatballs and 2 wet noodles showed positive results containing formaldehyde. This shows that around $33.3 \%$ of the meatball sample and $6.66 \%$ of the wet noodles sample analyzed were identified to contain formaldehyde so that they are not safe for consumption in the long term and people must be careful in selecting meatballs and wet noodles for consumption.
\end{abstract}

Keywords: Qualitative analysis, formalin, meatballs, wet noodles

\begin{abstract}
ABSTRAK. Bakso dan mie basah adalah makanan yang hingga kini popular digemari masyarakat. Kandungan kadar air yang tinggi menyebabkan kedua jenis makanan ini rentan dan mudah rusak dalam penyimpanannya. Penambahan bahan kimia seperti pengawet dalam pembuatan produk makanan dilakukan oleh produsen agar produknya menjadi lebih tahan lama, ekonomis, dan menghasilkan keuntungan maksimal. Salah satu bahan kimia yang sering disalahgunakan untuk pengawet makanan adalah formalin. Formalin merupakan bahan kimia berbahaya yang bersifat karsinogen, mutagenic, korosif dan iritatif. Penelitian ini bertujuan untuk mengetahui adanya kandungan formalin pada bakso dan mie basah di kecamatan Sukarame, Wayhalim dan Sukabumi. Penelitian ini dilakukan secara analisis kualitatif dengan menggunakan pereaksi Schif terhadap 30 sampel bakso dan 30 sampel mie basah yang dijual di kecamatan Sukarame, Wayhalim dan Sukabumi. Hasil penelitian menunjukkan bahwa 10 sampel bakso dan 2 mie basah mengandung formalin. Hal ini menunjukkan bahwa sekitar $33,3 \%$ dari sampel Bakso dan 6,66 \% dari sampel Mie Basah yang dianalisis dan beredar di tiga kecamatan di kota Bandar Lampung teridentifikasi mengandung formalin sehingga tidak aman untuk dikonsumsi dalam jangka panjang dan masyarakat harus berhati-hati dalam pemilihan bakso dan mie basah untuk di konsumsi.
\end{abstract}

Kata kunci: Analisis kualitatif, formalin, bakso, mie basah

Riwayat artikel: Diterima 12 November 2020, Disetujui 3 Desember 2020

Cara sitasi: Fauziyya, R., \& Saputro, AH. (2020). Analisis Formalin Secara Kualitatif pada Bakso dan Mie Basah di Kecamatan Sukarame, Wayhalim, dan Sukabumi. KOVALEN: Jurnal Riset Kimia, 6(3): 218-223.

DOI: https://doi.org/10.22487/kovalen.2020.v6.i3.15333 


\section{LATAR BELAKANG}

Bakso merupakan makanan berbentuk bola-bola dengan bahan dasar daging dan tepung. Bakso biasanya disajikan dengan kuah panas (Sunarlim, 1992). Bakso adalah produk makanan tradisional olahan daging yang terkenal dan digemari masyarakat, karena memiliki kandungan gizi yang tinggi dan rasanya yang enak. Kandungan protein dan kadar air dalam bakso tergolong tinggi, sehingga mudah terjadi kerusakan dalam penyimpanannya. Daya penyimpanan maksimal bakso hanya 1 hari pada suhu ruang (Purnomo, 1998). Menurut Standar Nasional Indonesia-SNI 013818-2014, bakso daging memiliki pesyaratan mengandung kadar air tidak lebih dari $70 \%$, minimum mengandung $11 \%$ protein (BSN, 2014).

Mie adalah makanan yang lazim dan digemari oleh masyarakat, mulai dari usia muda sampai tua karena mie harganya yang ekonomis dan cara pengolahannya juga mudah (Baihaqi, 2014). Salah satu jenis mie yang banyak digemari oleh masyarakat yaitu mie basah. Mie basah merupakan jenis mie mentah yang harus direbus terlebih dahulu sebelum dipasarkan. Kandungan kadar air dalam mie basah sekitar $52-60 \%$. Kandungan air yang cukup tinggi membuat mie basah tidak dapat bertahan lama dalam penyimpanannya (Yulianti \& Safira, 2020).

Bahan kimia berbahaya yang sering kali digunakan dalam mengawetkan produk makanan adalah formalin. Formalin banyak dimanfaatkan sebagai alternatif dalam mengawetkan makanan dikarenakan harganya yang murah dibandingkan dengan pengawet makanan yang diperbolehkan seperti natrium benzoat. Bahan pengawet formalin digunakan untuk juga untuk membasmi hama, disifektan, dan untuk pengawet pada mayat (Wijaya, 2011).

Formalin merupakan bahan kimia berbahaya karena bersifat karsinogen dan mutagenik yaitu dapat mengakibatkan terjadinya perubahan pada sel serta jaringan tubuh, dan juga memiliki sifat iritatif dan korosif. Uap formalin sangat berbahaya apabila terhirup melalui saluran pernafasan dan dapat menumbulkan efek iritasi ketika tertelan. Efek negatif formalin yang lain yaitu merusak sistem persarafan pada tubuh manusia dan mengganggu kesehatan organ reproduksi (Sajiman et al., 2015). Permenkes No. 33 Tahun 2012 menyatakan bahwa penggunaan dari formalin sebagai bahan tambahan pada makanan telah dilarang (Kemenkes RI, 2012).

Suatu studi telah dilakukan untuk menguji keamanan pangan produk daging, ikan dan olahannya di Bandar Lampung. Ditemukan bahwa formalin masih banyak digunakan sebagai bahan pengawet dalam berbagai jenis produk olahan daging dan ikan (Herdiana \& Satyajaya, 2016). Berdasarkan studi tersebut dan uraian diatas, maka peneliti tertarik melakukan penelitian terhadap analisis formalin secara kualitatif pada produk yang favorit dikonsumsi masyarakat Bandar Lampung yaitu bakso dan mie basah. Sampel diambil dari tiga kecamatan Bandar Lampung, yaitu Kecamatan Sukarame, Sukabumi dan Wayhalim. Diharapkan penelitian ini dapat menggambarkan tingkat kesadaran penjual bakso dan mie basah mengenai penggunaan bahan berbahaya dalam produknya.

\section{METODE PENELITIAN}

\section{Bahan dan Peralatan}

Penelitian ini menggunakan 10 sampel bakso dan 10 sampel mie basah dari 
kecamatan Sukarame (A), 10 sampel bakso dan 10 sampel mie basah dari kecamatan Wayhalim (B), dan 10 sampel bakso dan 10 sampel mie basah dari kecamatan Sukabumi (C). Pengujian kualitatif terhadap formalin dilakukan dengan menggunakan Reagen $A$ dan Reagen B Test Kit Formalin (Pereaksi Schif) merk Easy Test dan akuades.

Alat-alat yang digunakan yaitu alat-alat gelas seperti vial, gelas kimia, pipet tetes, batang pengaduk dan mortar stamper.

\section{Prosedur Penelitian}

\section{Analisis kualitatif kandungan formalin}

Analisis kualitatif dalam penelitian ini dilakukan menggunakan pereaksi Schif, dengan menggunakan Kit Formalin Merk Easy Test dan mereplikasi setiap sampel sebanyak 3 kali. Pertama cincang bakso /mie basah, ambil 10 gram kemudian masukkan kedalam wadah, tambahkan air panas sebanyak $20 \mathrm{ml}$, aduk dan tutup dan biarkan dingin sampai 15 menit. Ambil $5 \mathrm{ml}$ air rendaman tersebut, tambahkan reangen A sebanyak 4 tetes, aduk. Tambahkan reagen $B$ sebanyak 4 tetes lalu di aduk lagi, kemudian diamkan selama 15 menit. Warna ungu terbentuk artinya positif mengandung formalin (Maifita \& Handayani, 2020).

\section{HASIL DAN PEMBAHASAN}

\section{Hasil kualitatif kandungan formalin}

Sampel yang dianalisis berjumlah 60 sampel masing-masing 30 sampel bakso dan 30 sampel mie basah dari 3 kecamatan di Bandar Lampung,

Dari hasil pengamatan terhadap sampel bakso dengan test kit uji formalin, didapati perubahan warna pada 10 dari 30 sampel bakso, yang menunjukkan bahwa sampel tersebut benar mengandung formalin (Tabel 1). Sampel bakso yang mengalami perubahan warna menjadi ungu setelah diuji dengan test kit formalin adalah sampel dari Sukarame yaitu BA1, BA4, dan BA6, sampel dari Way Halim yaitu $B B 1$, dan $B B 7$, dan sampel dari Sukabumi yaitu $\mathrm{BC} 2, \mathrm{BC} 4, \mathrm{BC}$, $\mathrm{BC}$, dan $\mathrm{BC} 10$. Hasil pengamatan terhadap mie basah dengan test kit uji formalin, didapati perubahan warna pada 2 dari 30 sampel mie basah (Tabel 2). Perubahan warna menjadi ungu pada mie basah yang diuji dengan test kit formalin terjadi pada sampel dari kecamatan Way Halim yaitu MB1, dan dikecamatan Sukabumi yaitu MC9. Hal ini menunjukkan bahwa 33,3\% dari sampel bakso dan 6,66 \% dari sampel mie Basah yang dianalisis dan beredar di tiga kecamatan di kota Bandar Lampung teridentifikasi mengandung formalin. Perubahan warna menjadi ungu pada sampel yang positif mengandung formalin dapat dilihat pada Gambar 1.

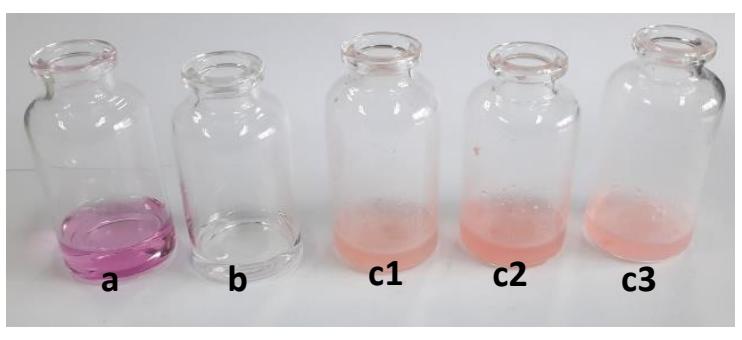

Gambar 1. (a) Kontrol Positif Formalin, (b) Kontrol Negatif Formalin (c) Sampel Positif Formalin Replikasi 3 kali

Saputrayadi et al. (2018) telah melakukan penelitian mengenai analisis kandungan boraks dan formalin pada beberapa pedagang bakso di kota Mataram, dan didapatkan hasil bahwa dari 12 sampel yang dikumpulkan, tidak ada yang mengandung boraks (0\%), tetapi $100 \%$ mengandung formalin. Penelitian lain yang dilakukan di Kota Langsa juga menunjukkan sebanyak $30,4 \%$ sampel dari bakso yang diuji positif mengandung formalin (Nasution et al., 2018). Hal ini menunjukkan rendahnya 
kesadaran masyarakat akan bahaya penggunaan formalin dalam makanan.

Tabel 1. Hasil pengamatan kandungan formalin pada sampel bakso

\begin{tabular}{cccccc}
\hline \multirow{2}{*}{ no } & \multirow{2}{*}{ Sampel } & \multirow{2}{*}{ kode } & \multicolumn{3}{c}{ replikasi } \\
\cline { 3 - 6 } & & & 1 & 2 & 3 \\
\hline 1 & Bakso A1 & BA1 & + & + & + \\
2 & Bakso A2 & BA2 & - & - & - \\
3 & Bakso A3 & BA3 & - & - & - \\
4 & Bakso A4 & BA4 & + & + & + \\
5 & Bakso A5 & BA5 & - & - & - \\
6 & Bakso A6 & BA6 & + & + & + \\
7 & Bakso A7 & BA7 & - & - & - \\
8 & Bakso A8 & BA8 & - & - & - \\
9 & Bakso A9 & BA9 & - & - & - \\
10 & Bakso A10 & BA10 & - & - & - \\
11 & Bakso B1 & BB1 & + & + & + \\
12 & Bakso B2 & BB2 & - & - & - \\
13 & Bakso B3 & BB3 & - & - & - \\
14 & Bakso B4 & BB4 & - & - & - \\
15 & Bakso B5 & BB5 & - & - & - \\
16 & Bakso B6 & BB6 & - & - & - \\
17 & Bakso B7 & BB7 & + & + & + \\
18 & Bakso B8 & BB8 & - & - & - \\
19 & Bakso B9 & BB9 & - & - & - \\
20 & Bakso B10 & BB10 & - & - & - \\
21 & Bakso C1 & BC1 & - & - & - \\
22 & Bakso C2 & BC2 & + & + & + \\
23 & Bakso C3 & BC3 & - & - & - \\
24 & Bakso C4 & BC4 & + & + & + \\
25 & Bakso C5 & BC5 & - & - & - \\
26 & Bakso C6 & BC6 & - & - & - \\
27 & Bakso C7 & BC7 & - & - & - \\
28 & Bakso C8 & BC8 & + & + & + \\
29 & Bakso C9 & BC9 & + & + & + \\
30 & Bakso C10 & BC10 & + & + & + \\
\hline & & & & &
\end{tabular}

Permenkes RI No.033 tahun 2012 Tentang Bahan Tambahan Pangan menyatakan bahwa penggunaan formalin pada makanan telah dilarang (Kemenkes RI, 2012). Larangan formalin sebagai pengawet dalam makanan ini dikarenakan sifarnya yang karsinogenik sehingga bisa memicu terjadinya kanker. Efek karsinogennya telah dipastikan oleh Lembaga Perlindungan Lingkungan Amerika Serikat (EPA) dan Lembaga
Internasional untuk penelitian Kanker (IARC) (Swenberg et al., 2013).

Tabel 2. Hasil pengamatan kandungan formalin pada sampel mie basah

\begin{tabular}{llllll}
\hline \multirow{2}{*}{ no } & \multirow{2}{*}{ Sampel } & \multirow{2}{*}{ kode } & \multicolumn{3}{c}{ replikasi } \\
\cline { 5 - 6 } & & & 2 & 3 \\
\hline 1 & Mie Basah A1 & MA1 & - & - & - \\
2 & Mie Basah A2 & MA2 & - & - & - \\
3 & Mie Basah A3 & MA3 & - & - & - \\
4 & Mie Basah A4 & MA4 & - & - & - \\
5 & Mie Basah A5 & MA5 & - & - & - \\
6 & Mie Basah A6 & MA6 & - & - & - \\
7 & Mie Basah A7 & MA7 & - & - & - \\
8 & Mie Basah A8 & MA8 & - & - & - \\
9 & Mie Basah A9 & MA9 & - & - & - \\
10 & Mie Basah A10 & MA10 & - & - & - \\
11 & Mie Basah B1 & MB1 & + & + & + \\
12 & Mie Basah B2 & MB2 & - & - & - \\
13 & Mie Basah B3 & MB3 & - & - & - \\
14 & Mie Basah B4 & MB4 & - & - & - \\
15 & Mie Basah B5 & MB5 & - & - & - \\
16 & Mie Basah B6 & MB6 & - & - & - \\
17 & Mie Basah B7 & MB7 & - & - & - \\
18 & Mie Basah B8 & MB8 & - & - & - \\
19 & Mie Basah B9 & MB9 & - & - & - \\
20 & Mie Basah B10 & MB10 & - & - & - \\
21 & Mie Basah C1 & MC1 & - & - & - \\
22 & Mie Basah C2 & MC2 & - & - & - \\
23 & Mie Basah C3 & MC3 & - & - & - \\
24 & Mie Basah C4 & MC4 & - & - & - \\
25 & Mie Basah C5 & MC5 & - & - & - \\
26 & Mie Basah C6 & MC6 & - & - & - \\
27 & Mie Basah C7 & MC7 & - & - & - \\
28 & Mie Basah C8 & MC8 & - & - & - \\
29 & Mie Basah C9 & MC9 & + & + & + \\
30 & Mie Basah C10 & MC10 & - & - & - \\
\hline & & & &
\end{tabular}

Formalin (formaldehida) merupakan senyawa kimia aldehida dengan rumus $\mathrm{H}_{2} \mathrm{CO}$. Formalin dalam bentuk larutan diketahui memiliki berbagai fungsi, diantaranya digunakan sebagai disinfektan dan dapat digunakan sebagai pengawet atau fiksatif di laboratorium. Formalin dapat meyebabkan efek fisiologis meningkatkan pelepasan histamin, dan imunitas yang dimediasi oleh sel. Secara kimia, formalin diklasifikasikan sebagai alergen. 
Formalin dalam air sifatnya mudah larut dan umumnya digunakan sebagai disinfektan serta digunakan untuk mengawetkan suatu spesimen biologi (Pub Chem, 2019).

Kadar maksimal formalin di udara yaitu tidak lebih dari $0.1 \mathrm{ppm}$ (part per million). Jika kadar formalin lebih dari batas yang telah disebutkan, maka dapat beresiko menyebabkan rasa terbakar pada hidung, mata, dan tenggorokan. Formalin juga dikenal dapat menyebabkan pusing, mual, dan iritasi pada kulit (Freeman et al., 2009). Penelitian yang pernah dilakukan sebelumnya terhadap pekerja pemakaman yang melakukan pembalseman menggunakan formalin menunjukkan bahwa ada peningkatan resiko kejadian kanker darah pada para pekerja tersebut (Hauptmann et al., 2009).

Sebuah penelitian dilakukan dengan memberikan formalin secara oral pada tikus albino, didapatkan hasil bahwa konsumsi formalin dapat menyebabkan keterlambatan perkembangan dan menginduksi perubahan histologis di korteks serebelar (Farhoud et al., 2019). Paparan formalin dalam waktu singkat dapat menyebabkan perubahan fungsi ginjal, peradangan dan perubahan morfologi. Formalin meningkatkan aktivitas superoksida dismutase sehingga menyebabkan kerusakan oksidatif (Ramos et al., 2017). Formalin juga telah dilaporkan dapat menginduksi toksisitas pada sumsum tulang tikus (Wei et al., 2017).

\section{KESIMPULAN}

Dari hasil pengamatan perubahan warna setelah direaksikan dengan test kit uji formalin dari 30 sampel Bakso yang diujikan diperoleh total 10 sampel dinyatakan mengandung formalin sedangkan 20 sampel lainnya tidak. Kemudian dari 30 sampel mie basah diperoleh total 2 sampel mengandung formalin sedangkan 28 sampel lainnya tidak. Hal ini menunjukkan bahwa sekitar 33,3 \% dari sampel Bakso dan 6,66 \% dari sampel Mie Basah yang dianalisis dan beredar di tiga kecamatan di kota Bandar Lampung teridentifikasi mengandung formalin, sehingga tidak aman untuk konsumsi jangka panjang dan masyarakat harus berhati-hati dalam memilih bakso dan mie basah.

Pada penelitian lanjutan disarankan melakukan uji kuantitaif formalin pada sampel Bakso dan Mie Basah yang positif mengandung formalin sehingga dapat diketahui seberapa besar konsentrasi formalin yang terkandung di dalamnya sehigga dapat dipastikan apakah kadarnya melebihi batas atau tidak.

\section{DAFTAR PUSTAKA}

Baihaqi, C. (2014). Sukses Wirausaha Gerobak Terlaris dan Tercepat Balik Modal. Kunci Aksara, Jakarta.

BSN. (2014). SNI 01-3818-2014 tentang Bakso Daging. Badan Standarisasi Nasional, Jakarta.

Farhoud, H., Abo Ouf, A., \& El-Soud, H. (2019). Histological Effect of Formaldehyde as Food Preservative on Cerebellar Cortex of Albino Rat. The Medical Journal of Cairo University, 87: 287-308. https://doi.org/10.21608/mjcu.2019.52352

Freeman, L. E. B., Blair, A., Lubin, J. H., Stewart, P. A., Hayes, R. B., Hoover, R. N., \& Hauptmann, M. (2009). Mortality from lymphohematopoietic malignancies among workers in formaldehyde industries: The National Cancer Institute Cohort. Journal of the National Cancer Institute, 101(10): 751-761. https://doi.org/10.1093/jnci/djp096

Hauptmann, M., Stewart, P. A., Lubin, J. H., Beane Freeman, L. E., Hornung, R. W., Herrick, R. F., Hoover, R. N., Fraumeni, J. F., Blair, A., \& Hayes, R. B. (2009). Mortality from lymphohematopoietic malignancies and brain cancer among 
embalmers exposed to formaldehyde. Journal of the National Cancer Institute, 101(24): 1696-1708. https://doi.org/10.1093/jnci/djp416

Herdiana, N., \& Satyajaya, W. (2016). Studi Keamanan Pangan Produk Daging, Ikan dan Olahannya Di Bandar Lampung. Prosiding Seminar Nasional Riset Dan Industri 2016, 137-145. http://repository.Ippm.unila.ac.id/1798/

Kemenkes RI. (2012). Peraturan Menteri Kesehatan Republik Indonesia Nomor 33 Tahun 2012 Tentang Bahan Tambahan Pangan. Kementerian Kesehatan RI, Jakarta.

Maifita, Y., \& Handayani, T. (2020). Pemeriksaan Kandungan Zat Kimia Formalin Pada Ikan Asin Yang Dijual Di Pasar Pariaman Tahun 2018. Jurnal Katalisator, 5(1): 100-105. https://doi.org/10.22216/jk.v5i1.4631

Nasution, N. G., Ferasyi, T. R., \& Razali, R. (2018). Pemeriksaan Cemaran Formalin Dan Mikroba Pada Bakso Yang Dijual Di Beberapa Tempat Di Kota Langsa. JURNAL ILMIAH MAHASISWA VETERINER, 2(3): 288-295. https://doi.org/10.21157/jim vet..v2i3.7868

Pub Chem. (2019). Open Chemistry Database: Formaldehyde. (diakses di https://pubchem.ncbi.nlm.nih.gov/compou nd/formaldehyde\#section=Top, pada tanggal 2 Februari 2020).

Purnomo. (1998). Membuat Bakso Daging dan Daging Ikan. Kanisius, Yogyakarta.

Ramos, C. de O., Nardeli, C. R., Campos, K. K. D., Pena, K. B., Machado, D. F., Bandeira, A. C. B., Costa, G. de P., Talvani, A., \& Bezerra, F. S. (2017). The exposure to formaldehyde causes renal dysfunction, inflammation and redox imbalance in rats. Experimental and Toxicologic Pathology, 69(6): 367-372. https://doi.org/10.1016/j.etp.2017.02.008

Sajiman, S., Nurhamidi, N., \& Mahpolah, M. (2015). Kajian Bahan Berbahaya Formalin, Boraks, Rhodamin B Dan Methalyn Yellow Pada Pangan Jajanan Anak Sekolah Di Banjarbaru. Jurnal Skala
Kesehatan, $6(1)$. https://doi.org/10.31964/jsk.v6i1.26

Saputrayadi, A., Asmawati, A., Marianah, M., \& Suwati, S. (2018). Analisis Kandungan Boraks Dan Formalin Pada Beberapa Pedagang Bakso Di Kota Mataram. Jurnal Agrotek Ummat, 5(2): 107-116. https://doi.org/10.31764/agrotek.v5i2.701

Sunarlim, R. (1992). Karakterisrik mutu bakso daging sapi dan pengaruh penambahan natrium klorida dan natrium tripolifosfat terhadap perbaikan mutu. [Disertasi]. Institut Pertanian Bogor, Bogor. http://repository.ipb.ac.id/handle/1234567 89/23164

Swenberg, J. A., Moeller, B. C., Lu, K., Rager, J. E., Fry, R., \& Starr, T. B. (2013). Formaldehyde Carcinogenicity Research: 30 Years and Counting for Mode of Action, Epidemiology, and Cancer Risk Assessment. Toxicologic Pathology, 41(2): 181-189. https://doi.org/10.1177/019262331246645 9

Wei, C., Wen, H., Yuan, L., McHale, C. M., Li, H., Wang, K., Yuan, J., Yang, X., \& Zhang, L. (2017). Formaldehyde induces toxicity in mouse bone marrow and hematopoietic stem/progenitor cells and enhances benzene-induced adverse effects. Archives of Toxicology, 91(2): 921-933. https://doi.org/10.1007/s00204-016-17605

Wijaya, D. (2011). Waspadai Zat Aditif dalam Makananmu. Buku Biru, Yogyakarta.

Yulianti, C. H., \& Safira, A. N. (2020). Analisis Kandungan Formalin pada Mie Basah Menggunakan Nash dengan Metode Spektrofotometri UV-Vis. Journal of Pharmacy and Science, 5(1): 7-14. 